Vol 2 No 2 (2019) 234-251 P-ISSN 2620-295 E-ISSN 2747-0490

DOI: $1047467 /$ elmal.v2i2.550

\title{
Pelayanan yang Baik terhadap Nasabah sebagai Motivasi Menabung di Bank Muamalat Cabang Pembantu Stabat
}

\author{
Asmawarna Sinaga1, Anjur Perkasa Alam², Muhammad Hazigun Nawawi³, Nurul \\ Sifana ${ }^{4}$ \\ 1,2,3,4Sekolah Tinggi Agama Islam Jam'iyah Mahmudiyah Tanjung Pura \\ Asmawarna.sinaga@yahoo.co.id ${ }^{1}$,anjurpohan@gmail.com²
}

\begin{abstract}
.
The good service to customers as motivation to save at bank Muamalat branch Stabat. Asmawarna Sinaga and Anjur Perkasa Alam. This research explains about good service to customer as motivation of saving at Bank Muamalat Branch stabat. The good service is the services provided to customers, so that customers feel comfortable saving at Bank Muamalat. Motivation to save is the encouragement given by bank employees to their customers so that the customer becomes loyal to save at Bank Muamalat Stabat. This research is a qualitative research. Sources of data used are primary data and secondary data. Methods of data collection by doing obsevation, documentation and interviews. Data analysis techniques using data reduction, data presentation and conclusion drawing. The result of the research of Bank Muamalat is the bank in the city of Stabat. It is very strategic and makes it easy for Stabat people to find it. Good service provided by employees of Bank Muamalat Branch stabat make customers feel comfortable to save at the Bank. So the result of good service research on the customer as a motivation to save in the bank Muamalat Branch Stabat is good and many customers who feel comfortable to join become customers of Bank Muamalat.
\end{abstract}

Keywords: Good Service, Motivation Saving.

\begin{abstract}
ABSTRAK.
Pelayanan yang baik terhadap nasabah sebagai motivasi menabung di Bank Muamalat Cabang Pembantu Stabat. Asmawarna Sinaga dan Anjur Perkasa Alam. Penelitian ini menjelaskan mengenai pelayanan yang baik terhadap nasabah sebagai motivasi menabung di Bank Muamalat Cabang pembantu stabat. Adapun pelayanan yang baik adalah layanan yang diberikan kepada nasabah, sehingga nasabah tersebut merasa nyaman menabung di Bank Muamalat. Motivasi menabung adalah dorongan yang diberikan oleh karyawan bank kapada nasabahnya agar nasabah tersebut menjadi loyal menabung di Bank Muamalat Stabat. Penelitian ini merupakan penelitian kualitatif. Sumber data yang digunakan adalah data primer dan data skunder. Metode pengumpulan data dengan melakukan observasi, dokumentasi dan wawancara. Tehnik analisis data dengan menggunakan reduksi data, penyajian data dan penarikan kesimpulan. Hasil dari penelitian Bank Muamalat adalah bank yang di kota Stabat. Letaknya sangat strategis dan memudahkan masyarakat Stabat untuk menemukannya. Pelayanan yang baik diberikan oleh karyawan Bank Muamalat Cabang stabat membuat nasabah merasa nyaman untuk menabung di Bank tersebut. Maka hasil dari penelitian pelayanan yang baik terhadap nasabah sebagai motivasi
\end{abstract}




\section{Vol 2 No 2 (2019) 234-251 P-ISSN 2620-295 E-ISSN 2747-0490 DOI: $1047467 /$ elmal.v2i2.550}

menabung di bank Muamalat Cabang Pembantu Stabat adalah baik dan banyak nasabah yang merasa nyaman bergabung menjadi nasabah Bank Muamalat.

\section{Kata kunci : Pelayanan yang Baik, Motivasi Menabung.}

\section{PENDAHULUAN}

Lembaga keuangan yang mendapatkan kepercayaan masyarakat atas dananya, bank semaksimal mungkin melakukan daya tarik ekonomi berupa bunga tinggi, bonus serta hadiah yang menarik. Berbagai cara dilakukan bank dengan tujuan meningkatkan penghimpunan dana dari masyarakat yang salah satu caranya adalah meningkatkan volume nasabahnya. ${ }^{1}$

Perbankan syariah dalam peristilahan internasional dikenal sebagai Islamic Banking atau disebut dengan interest-free banking. ${ }^{2}$ Seperti halnya bank Konvensional, bank syariah mempunyai fungsi utama yaitu menghimpun dana masyarakat dan menyalurkan kembali dana tersebut ke masyarakat serta memberi jasa bank lainnya. ${ }^{3}$

Dengan begitu bank berperan melancarkan transaksi perdagangan dan pembayaran serta memberi perlindungan keamanan uang dari berbagai gangguan, seperti perampokan. Begitu besar jasa pelayanan lembaga perbankan bagi negara dan masyarakat di zaman modern ini sehingga tidak salah bila dikatakan bahwa dalam satu negara harus berdiri bank; tanpa ada bank suatu negara akan kacau. Meskipun memberikan jasa pelayanan, tetapi bank bukan "lembaga sosial". Bank adalah lembaga yang bergerak dalam usaha dagang, karenanya keuntungan menjadi sangat penting dalam usahanya. ${ }^{4}$

Sebagai suatu badan usaha perbankan yang menganut sistem bagi hasil, perbankan syariah memiliki banyak keunggulan, sehingga menyebabkan pergerakan perekonomian Indonesia ke arah yang lebih positif ditandai dengan munculnya hal-hal baru dengan sistem syariah. Pada saat krisis moneter pada tahun 1997 di mana sejumlah bank konvensional akhirnya dilikuidasi karena tidak mampu melaksanakan

${ }^{1}$ Karnaen Parwatatmaja, Membuktikan Ekonomi Islam di Indonesia, (Depok: Usaha Kami, 1996), h. 179.

${ }^{2}$ Muhammad, Manajemen Bank Syariah,Edisi Revisi ke-2, (Yogyakarta: UPP STIM YKPN,2011), h. 15.

${ }^{3}$ Kashmir, Manajemen Perbankan, Edisi Revisi ke-10, (Jakarta: Rajawali Pers,2011), h. 11.

${ }^{4}$ M. Zukhri, Riba Dalam Al Qur'an dan Masalah Perbankan Sebuah Tilikan Antisifatif, (Jakarta Raja Grafindo Persada, 1997), h. 144-145. 


\section{Vol 2 No 2 (2019) 234-251 P-ISSN 2620-295 E-ISSN 2747-0490 DOI: $1047467 /$ elmal.v2i2.550}

kewajibannya terhadap nasabah sebagai akibat dari kebijakan bunga yang tinggi yang ditetapkan pemerintah selama krisis berlangsung.

Dalam kondisi tersebut, bank konvensional dengan sistem bunga mengalami pertumbuhan yang negatif sehingga menyebabkan sekitar 64 bank terlikuiditasi, namun tidak bagi bank syariah. Sebagai perbankan yang tidak menganut sistem bunga menyebabkan bank syariah tidak mengalami pergerakan negatif. Bank syariah tidak memiliki kewajiban untuk membayar bunga simpanan kepada para nasabahnya. Bank syariah hanya membayar bagi hasil kepada nasabahnya sesuai dengan keuntungan yang diperoleh bank dari hasil investasi yang dilakukannya. Selain itu, semakin bertambah jugalah bank-bank konvensional yang membuka cabang syariah ataupun melakukan konversi total ke sistem syariah.

Perkembangan Bank Syariah di Indonesia cukup berkembang pesat, walaupun demikian, jumlah bank maupun kantor bank yang sudah cukup banyak, namun jumlah aset bank syariah masih kecil dibandingkan dengan bank konvensional. Perbankan syariah yang masih muda umurnya, dituntut untuk bersaing dengan bank konvensional. Perbankan syariah juga dituntut untuk memainkan peranan yang sangat vital dalam menggerakkan roda perekonomian bangsa Indonesia.

Bank Muamalat didirikan dengan maksud untuk mempromosikan dan mengembangkan penerapan prinsip-prinsip syariah kedalam transaksinya. Bank muamalat yang merupakan bank syariah pertama yang berdiri memberikan pilihan produk dengan berbagai macam ragam. Produk yang ditawarkan sangat memudahkan nasabah untuk bertransaksi di Bank Muamalat tersebut. Disinilah peran Bank Muamalat untuk melakukan sosialisasi mengenai perbankan syariah, baik itu dari definisinya, lokasi nya, prinsipnya dan berbagai macam produknya. Agar nasabah paham bahwa perbankan syariah adalah bank yang menggunakan prinsip syariah.

Salah satu faktor paling mendasar dalam mengembangkan produk perbankan syariah dikalangan masyarakat adalah pengetahuan. Pengetahuan merupakan pengalaman aktual yang tersimpan dalam kesadaran manusia. Pengetahuan adalah informasi, informasi dapat diperoleh melalu berbagai media, seperti iklan pada televisi, koran, pamflet bahkan bisa juga dengan pengalaman seseorang yang telah menabung di Bank Muamalat.

Rumusan masalah dalam penelitian ini adalah bagaimana pelayanan kepada nasabah Bank Muamalat Cabang pembantu Stabat, Bagaimana meningkatkan motivasi nasabah menabung di Bank Muamalat Cabang Pembantu Stabat dan Faktor-faktor apa saja yang dapat memotivasi nasabah untuk menabung di Bank Muamalat Cabang pembantu Stabat.

Tujuan dari penelitian ini adalah untuk mengetahui pelayanan kepada nasabah Bank Muamalat Cabang pembantu Stabat, untuk mengetahui peningkatkan motivasi nasabah menabung di Bank Muamalat Cabang Pembantu Stabat dan untuk mengetahui 


\section{Vol 2 No 2 (2019) 234-251 P-ISSN 2620-295 E-ISSN 2747-0490 DOI: $1047467 /$ elmal.v2i2.550}

faktor-faktor apa saja yang dapat memotivasi nasabah untuk menabung di Bank Muamalat Cabang pembantu Stabat.

\section{TINJAUAN LITERATUR}

\section{Pelayanan kapada nasabah Perbankan Syariah}

Perbankan Syariah adalah bank yang menjalankan perintahnya sesuai dengan prinsip syariah. Dimana yang dimaksud dengan prinsip syariah adalah aturan perjanjian berdasarkan hukum islam antar bank dan pihak lain untuk menyimpan dana dan atau pembiayaan untuk kegiatan lainnya yang dinyatakan sesuai dengan syariah, antara lain pembiayaan berdasarkan prinsip bagi hasil, pembiayaan berdasarkan prinsip penyertaan modal, prinsip jual beli barang dengan memperoleh keuntungan, atau pembiayaan berdasarkan prinsip sewa murni tanpa pilihan, atau dengan adanya pilihan pemindahan kepemilikan atas barang yang disewakan dari pihak bank ke pihak lain.

Menurut Undang-undang RI Nomor 10 Tahun 1998 tanggal 10 November 1998 tentang perbankan adalah badan usaha yang menghimpun dana dari masyarakat dalam bentuk-bentuk lainnya dalam rangka meningkatkan taraf hidup rakyat banyak. ${ }^{5}$ Sedangkan Menurut Undang-undang Nomor 21 tahun 2008 tentang perbankan syariah, "Perbankan Syariah" adalah segala sesuatu yang menyangkut tentang bank syariah dan unit usaha syariah, mencakup kelembagaan, kegiatan usaha, cara dan proses dalam melaksanakan kegiatan usahanya Dengan demikian perbankan syariah dapat dipahami secara detail. Bank syariah adalah lembaga keuangan yang disesuaikan dengan prinsip-prinsip syariah.

Menurut Perwaatmadja "Bank Syariah adalah bank yang tata cara operasinya mengikuti ketentuan-ketentuan syariah Islam". Salah satu yang harus dijauhi dalam muamalah Islam adalah praktik-praktik yang mengandung unsur riba. Sedangkan menurut Bank Syariah adalah Bank yang beroperasi dengan tidak mengandalkan pada bunga. Yakni mengacu kepada ketentuan-ketentuan Al-quran dan Hadis. ${ }^{6}$

Dimana yang dimaksud dengan perbankan syariah adalah segala sesuatu yang menyangkut tentang Bank Syariah dan Unit Usaha Syariah, mencakup kelembagaan, kegiatan usaha, serta cara dan proses dalam melaksanakan kegiatan usahanya. Perbankan Syariah merupakan bank yang menerapkan nilai-nilai syariah salah satu diantaranya pelarangan unsur riba, seperti dijelaskan di beberapa ayat Al-Qur'an dalam Surat Al-Imran :130 sebagai berikut :

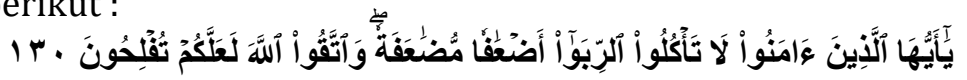

\footnotetext{
${ }^{5}$ Kasmir, Manajemen Perbankan (Jakarta : PT Raja Grafindo Persada, 2010), h. 12.

${ }^{6}$ Ismail, Perbankan Syariah (Jakarta: Kencana Prenada Media Group, 2011), h.32.
} 


\section{Vol 2 No 2 (2019) 234-251 P-ISSN 2620-295 E-ISSN 2747-0490 DOI: $1047467 /$ elmal.v2i2.550}

Artinyan : "Hai orang-orang yang beriman, janganlah kamu memakan riba dengan berlipat ganda dan bertakwalah kamu kepada Allah supaya kamu mendapat keberuntungan".7

Dari ayat diatas, dapat dijelaskan tentang pengertian riba, yaitu : yang dimaksud riba di sini ialah riba nasi'ah. menurut sebagian besar ulama bahwa riba nasi'ah itu selamanya Haram, walaupun tidak berlipat ganda. Riba itu ada dua macam: nasiah dan fadhl. riba nasiah ialah pembayaran lebih yang disyaratkan oleh orang yang meminjamkan. riba fadhl ialah penukaran suatu barang dengan barang yang sejenis, tetapi lebih banyak jumlahnya Karena orang yang menukarkan mensyaratkan demikian, seperti penukaran emas dengan emas, padi dengan padi, dan sebagainya. riba yang dimaksud dalam ayat Ini riba nasiah yang berlipat ganda yang umum terjadi dalam masyarakat Arab zaman Jahiliyah.

Allah Swt berfirman mengenai riba dalam An Nisa : 39, yaitu :

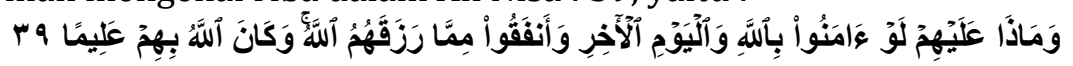

Artinya :"Dan disebabkan mereka memakan riba, padahal Sesungguhnya mereka Telah dilarang daripadanya, dan Karena mereka memakan harta benda orang dengan jalan yang batil. kami Telah menyediakan untuk orang-orang yang kafir di antara mereka itu siksa yang pedih"."

Permasalahn riba inilah yang menjadi tolak ukur nasabah lebih memilih menyimpan uangnya di Bank Syariah. Sistem bagi hasil yang ditawarkan oleh Bank Syariah ini lah yang sangat menarik minat nasabah.

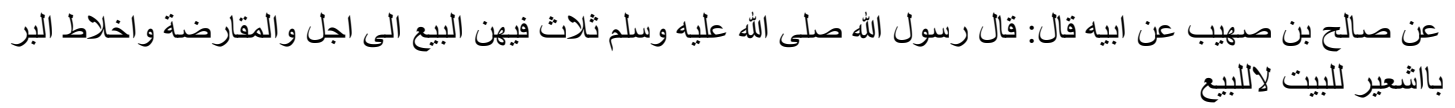

Artinya: "Dari Shahih bin Shuhaib r.a. bahwa Rasulullah saw. Bersabda, "Tiga hal yang di dalamnya terdapat keberkatan: jual beli secara tangguh, muqaradhah (mudharabah), dan mencampur gandum dengan tepung untuk keperluan rumah, bukan untuk dijual". ${ }^{9}$ (HR. Ibnu Maja).

\section{Kualitas Pelayanan Nasabah}

Menurut kamus besar bahasa Indonesia, pelayanan berasal dari kata "layan" yang artinya membantu menyiapkan (mengurus) apa-apa yang diperlukan seseorang. Jadi, kata "pelayanan" adalah: Perihal atau cara melayani, usaha melayani kebutuhan orang

\footnotetext{
${ }^{7}$ Departemen Agama RI, Al-Qur'an dan Terjemah, (Jakarta: Pustaka assalam, 2010),Surat Al-Imran :130, h. 66.

${ }^{8}$ Departemen Agama RI, Al-Qur'an dan Terjemah,..., h. 85

${ }^{9}$ Muhammad Syafi'i Antonio, Bank Syariah dari Teori ke Praktek,... , h. 96.
} 


\section{Vol 2 No 2 (2019) 234-251 P-ISSN 2620-295 E-ISSN 2747-0490 DOI: $1047467 /$ elmal.v2i2.550}

lain dengan memperoleh imbalan, kemudahan yang diberikan sehubungan dengan jual beli barang atau jasa. ${ }^{10}$

Dalam definisi lain, menyebutkan pelayanan adalah sebagai suatu tindakan atau perbuatan seseorang atau organisasi untuk memberikan kepuasan kepada pelanggan atau nasabah. Tindakan tersebut dapat dilakukan melalui cara langsung melayani pelanggan. ${ }^{11}$ Layanan pelanggan adalah sebagai sebuah fungsi tentang sebaik apa sebuah organisasi bisa konsisten memenuhi dan melampaui kebutuhan pelanggan.

Dalam hal ini, bentuk layanan terbagi menjadi dua bagian yaitu: Pelayanan yang baik. Dalam melayani nasabah, hal-hal yang perlu diperhatikan adalah kepuasan nasabah terhadap pelayanan yang diberikan. Puas artinya nasabah akan merasa semua keinginan dan kebutuhannya dapat dilakukan secara tepat waktu. Berikut ini ciri-ciri pelayanan yang baik adalah sebagai berikut: Tersedianya sarana dan prasarana yang baik. Nasabah ingin dilayani secara prima. Untuk melayani nasabah salah satu yang paling penting diperhatikan adalah sarana dan prasarana yang dimiliki bank. Meja dan kursi nyaman untuk diduduki. Udara dalam ruangan harus tetap tenang, tidak berisik dan sejuk. Kelengkapan dan kenyamanan sarana dan prasarana ini akan mengakibatkan nasabah betah untuk berurusan dengan bank. Tersedianya personil yang baik. Kenyamanan nasabah juga tergantung dari karyawan yang melayaninya. Karyawan harus ramah, sopan dan menarik. Karyawan juga harus mampu memikat dan mengambil hati nasabah, sehingga semakin tertarik. Jadi, sebelum menjadi karyawan harus melalui pendidikan dan pelatihan khusus. Bertanggung jawab kepada setiap nasabah sejak awal hingga selesai dalam menjalankan kegiatan pelayanan. Karyawan harus mampu melayani dari awal sampai tuntas atau selesai. Nasabah akan merasa puas jika karyawan bertanggung jawab terhadap pelayanan yang diinginkannya.

Mampu melayani secara cepat dan tepat. Dalam melayani nasabah diharapkan karyawan harus melakukan sesuai prosedur. Layanan yang diberikan harus sesuai jadwal untuk pekerjaan tertentu dan jangan membuat kesalahan dalam arti pelayanan yang diberikan tidak sesuai dengan keinginan nasabah.

Mampu berkomunikasi. Karyawan harus mampu berbicara kepada setiap nasabah dan karyawan pun mampu dengan cepat memahami keinginan nasabah. Artinya karyawan harus dapat berkomunikasi dengan bahasa yang jelas dan mudah dimengerti. Jangan menggunakan istilah yang sulit dimengerti.

Memberikan jaminan kerahasiaan setiap transaksi. Menjaga rahasia bank sama artinya menjaga rahasia nasabah. Oleh karena itu, petugas karyawan harus mampu menjaga rahasia nasabah terhadap siapapun. Rahasia bank merupakan taruhan kepercayaan nasabah kepada bank.

\footnotetext{
${ }^{10}$ Departemen Pendidikan Nasional, Kamus Besar Bahasa Indonesia (Jakarta: Balai Pustaka, 2007), h. 647.

${ }^{11}$ Kasmir, Etika Customer Service (Jakarta: Raja Grafindo Persada, 2011), h. 15.
} 


\section{Vol 2 No 2 (2019) 234-251 P-ISSN 2620-295 E-ISSN 2747-0490 DOI: $1047467 /$ elmal.v2i2.550}

Memiliki pengetahuan dan kemampuan yang baik. Untuk menjadi customer service harus memiliki pengetahuan dan kemampuan tertentu. Karena tugas customer service selalu berhubungan dengan nasabah maka customer service perlu dididik khusus mengenai kemampuan dan pengetahuannya untuk menghadapi nasabah atau kemampuan dalam bekerja.

Berusaha memahami kebutuhan nasabah. Customer service harus cepat dan tanggap dengan apa yang diinginkan oleh nasabah. ${ }^{17}$ karyawan yang lamban akan membuat nasabah lari. Usahakan mengerti dan pahami keinginan dan kebutuhan nasabah.

Sehingga pelayanan yang baik dapat menimbulkan sisi positif bagi perusahaan. Karena pelanggan akan merasa puas dengan pelayanan yang diberikan. Pelayanan yang tidak baik. Setiap hal tentu tidak terlepas dari dua sisi, ada yang baik ada juga yang buruk. Pelayanan yang buruk tentu akan dapat berakibat fatal bagi sebuah perusahaan, pada akhirnya perusahaan tidak akan mendapatkan kepercayaan dari para pelanggannya, perlahan-lahan pelanggan akan meninggalkan perusahaan tersebut apabila pelayanan yang diberikan tidak baik, berikut beberapa kriteria pelayanan yang tidak baik: Membiarkan pelanggan menunggu lama, selalu terlambat, gagal menghargai waktu pelanggan, Membuat janji tapi tidak di tepat, Terlalu sok akrab hingga melewati Batasan, Kurangnya keterampilan berkomunikasi, Service yang tidak konsisten, kadang bagus kadang buruk, Terlalu sering mengganti karyawan, Kurangnya keterampilan menangani complaint., Tidak mengucapkan terima kasih diakhir transaksi dan Kurangnya keterampilan menjual. ${ }^{12}$ Apabila pelayanan yang diberikan tidak baik kepada pelanggan maka akan berdampak buruk bagi perusahaan. Karena pelanggan merasa tidak puas atas pelayanannya.

Kualitas adalah keseluruhan ciri serta sifat dari suatu produk atau jasa yang berpengaruh pada kemampuannya untuk memuaskankebutuhan yang dinyatakan atau yang tersirat. ${ }^{13}$ Kualitas layanan dapat didefinisikan sebagai seberapa jauh perbedaan antara kenyataan dan harapan para pelanggan atas layanan yang mereka terima. Kualitas layanan dapat diketahui dengan cara membandingkan persepsi para pelanggan atas layanan yang benar-benar telah mereka terima.

Kualitas pelayanan dapat diukur baik atau tidaknya berdasarkan sudut pandang nasabah bukan berdasarkan penyedia jasa. Meskipun demikian, bukan berarti kualitas pelayanan tidak dapat diukur. Persepsi terhadap kualitas pelayanan didefinisikan sebagai penilaian menyeluruh atas keunggulan suatu jasa.

${ }^{12}$ Ivonne Wood, Layanan Pelanggan (Yogyakarta: Graha Ilmu, 2009), h. 6.

${ }^{13}$ Philip Kotler, Manajemen Pemasaran: Analisis, Perencanaan, Implementasi dan Kontrol, Edisi 9, Terjemahan : Hendra Tegush, (Jakarta: Prendhallindo, 2000), h. 137. 


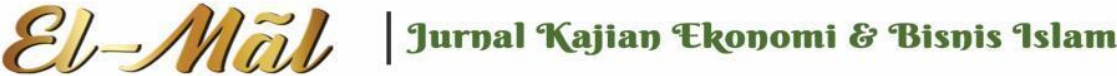

\section{Vol 2 No 2 (2019) 234-251 P-ISSN 2620-295 E-ISSN 2747-0490 DOI: $1047467 /$ elmal.v2i2.550}

Bank yang menganut konsep pelayanan jelas akan mengorientasikan diri pada nasabah dan mengutamakan kepuasan nasabah. Terciptanya situasi yang seperti ini akan membentuk kekuatan bagi bank dalam menghadapi persaingan dan melayani pelanggan dengan sebaik mungkin.

Nasabah adalah orang atau badan hukum yang mempunyai rekening baik rekening simpan maupun rekening pinjaman pada pihak bank yang dapat berhubungan dengan atau menjadi pelanggan bank. ${ }^{14}$ Dengan kata lain nasabah ini adalah pihak atau orang yang menggunakan dan secara sengaja menjadi langganan bank yang dipercaya. Salah satu tujun utama perbankan adalah untuk meningkatkan jumlah nasabah dengan memberkan pelaynana yang baik. Dengan pelayanan yang cepat dan tanpa menunggu terlalu lama. Hal ini membuat kepuasan bagi nasabah tersendiri.

Menurut kamus populer Bahasa Indonesia nasabah adalah " orang yang biasa berhubungan dengan atau menjadi pelanggan bank".15 Menurut kamus ilmiah populer nasabah adalah "pertalian; perhubungan; perbandingan; sahabat; ansab; saudara; kerabat; langganan; pelanggan". ${ }^{16}$ Berdasarkan pejelasan diatas dapat disimpulkan bahwa nasabah adalah orang yang menjadi pelanggan di sebuah bank.

Nasabah adalah kunci dari kesuksesan sebuah bank. Persaingan didunia perbankan saat ini sangat ketat dalam hal mencari nasabah. Berbagai jenis keunggulan yang ditawarkan oleh bank untuk menarik minat nasabah menyimpan uang atau menabung di bank tersebut. Sebagaimana yang dikatakan oleh Slameto bahwa “ seseorang yang memiliki minat terhadap subyek tertentu cenderung untuk memberikan perhatian yang lebih besar terhadap subyek tersebut".

Islam mengajarkan bila ingin memberikan hasil usaha baik berupa barang maupun pelayanan jasa hendaknya memberikan yang berkualitas, jangan memberikan yang buruk atau tidak berkualitas kepada orang lain. Seperti dijelaskan dalam QS Albaqarah/ 2:267, yaitu :

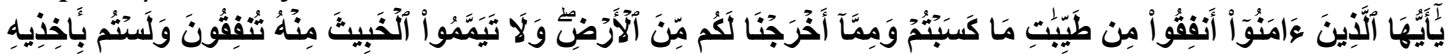

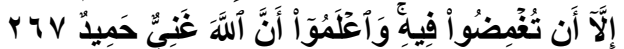

Artinya: "Hai orang-orang yang beriman, nafkahkanlah (di jalan allah) sebagian dari hasil usahamu yang baik-baik dan sebagian dari apa yang Kami keluarkan dari bumi untuk kamu. Dan janganlah kamu memilih yang buruk-buruk lalu kamu menafkahkan daripadanya, padahal kamu sendiri tidak mau

${ }^{14}$ Fauziah, Teknologi Informasi dalam Bisnin Reengineering, 1998, (Dalam Skripsi Mei Sandatul Husna Chusna: 2014).

${ }^{15}$ Eddy Soetrisno, Kamus Populer Bahasa Indonesia, (Bandung:Sinergi Pustaka Indonesia,2010), cet ke-2, h. 606.

${ }^{16}$ Tim Pustaka Agung Harapan, Kamus Ilmiah Populer, (Surabaya: Pustaka Agung Harapan, 2012), h. 450. 


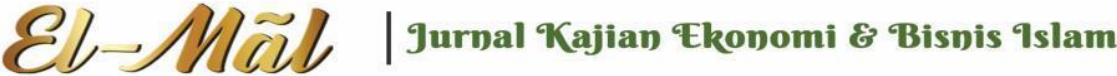

\section{Vol 2 No 2 (2019) 234-251 P-ISSN 2620-295 E-ISSN 2747-0490 DOI: $1047467 /$ elmal.v2i2.550}

mengambilnya melainkan dengan memincingkan mata terhadapnya. Dan ketahuilah, bahwa Allah Maha Kaya lagi Maha Terpuji. ${ }^{17}$

Kualitas layanan sebagai ukuran seberapa baik tingkat yang diberikan mampu sesuai dengan harapan pelanggan. Kualitas layanan adalah tingkat keunggulan yang diharapkan dan pengendalian atas tingkat keunggulan tersebut untuk memenuhi keinginan pelanggan.

Dalam mengevaluasi kepuasan terhadap produk jasa, atau perusahaan tertentu, nasabah umumnya mengacu pada berbagai faktor atau dimensi. Faktor-faktor yang sering digunakan dalam mengevaluasi kepuasan terhadap suatu produk diantaranya : kinerja, keistimewaan tambahan, daya tahan, dan daya tarik terhadap panca indra. ${ }^{18}$

Kualitas layanan sebagai ukuran seberapa baik tingkat yang diberikan mampu sesuai dengan harapan pelanggan. Kualitas layanan adalah tingkat keunggulan yang diharapkan dan pengendalian atas tingkat keunggulan tersebut untuk memenuhi keinginan pelanggan.

Dalam mengevaluasi kepuasan terhadap produk jasa, atau perusahaan tertentu, nasabah umumnya mengacu pada berbagai faktor atau dimensi. Faktor-faktor yang sering digunakan dalam mengevaluasi kepuasan terhadap suatu produk diantaranya : kinerja, keistimewaan tambahan, daya tahan, dan daya tarik terhadap panca indra. ${ }^{19}$

Terdapat lima dimensi kualitas jasa yang digunakan perbankan dalam mengevaluasi jasa, antar lain : Berwujud termasuk fasilitas fisik, Keandalan adalah kemampuan personil untuk melaksanakan secara bebas, Tanggapan adalah konsumen diberikan pelayanan dengan segera, Jaminan adalah pengetahuan dan etika pegawai, serta kemampuan mereka untuk membangkitkan kepercayaan dan keyakinan nasabah dan Empati adalah kepedulian dan kemampuan pegawai dan perhatian individu. ${ }^{20}$

Kegiatan usaha bank syariah dalam hal penghimpunan dana, bank syariah melakukan mobilisasi dan investasi tabungan dengan cara yang adil, sehingga keuntungan yang adil dapat dijamin bagi semua pihak. Tujuan mobilitas dana merupakan hal penting karena Islam secara tegas mengutuk penimbunan tabungan dan menuntut penggunaan sumber dana secara produktif dalam rangka mencapai tujuan sosial ekonomi Islam. ${ }^{21}$

Berkaitan dengan hal di atas, maka secara prinsip perbankan syariah melakukan upaya penghimpunan dana tidak dengan prinsip bunga (riba), melainkan dengan prinsip-

${ }^{17}$ Departemen Agama RI, Al-Qur'an dan Terjemahanny, (Jakarta: Pussaka Assala, 2010), h. 43

${ }^{18}$ Fandi Tjiptono, Strategi Pemasaran,..., h. 61.

${ }^{19}$ Fandi Tjiptono, Strategi Pemasaran,..., h. 61.

${ }^{20}$ Minor Michael, Perilaku Konsumen, Jilid II, (Jakarta: Erlangga, 2002), h. 91.

${ }^{21}$ Veithzal Rivai et.al., Credit Management Handbook, (Jakarta: Rienaka Cipta, 2001), h. 768. 


\section{Vol 2 No 2 (2019) 234-251 P-ISSN 2620-295 E-ISSN 2747-0490 DOI: $1047467 /$ elmal.v2i2.550}

prinsip yang sesuai dengan syariat Islam, terutama prinsip wadiah (titipan) dan mudharabah (bagi hasil).

Kualitas jasa menjadi salah satu keharusan yang dilakukan perusahaan supaya mampu bertahan dan tetap mendapatkan kepercayaan dari pada nasabahnya. Pola konsumsi dan gaya hidup menuntut perusahaan mampu memberikan produk jasa yang berkualitas. ${ }^{22}$

Total Quality Service merupakan sistem manajemen strategi dan integratif yang melibatkan semua manajer dan karyawan serta menggunakan berbagai metode untuk memperbaiki secara berkeseimbangan atas proses-proses organisasi agar dapat memenuhi dan melebihi kebutuhan, keinginan dan harapan pelanggan. ${ }^{23}$

Berdasarkan berbagai pendapat di atas, ada faktor utama yang mempengaruhi kualitas layanan, yaitu : jasa yang diharapkan dan jasa yang dirasakan oleh nasabah. Apabila jasa yang dirasakan sesuai dengan jasa yang diharapkan oleh nasabah, maka kualitas pelayanan tersebut dianggap baik oleh nasabahnya. Begitu sebalikanya jika tidak sesuai yang diharapkan dan yang dirasakan, maka kualitas pelayanan itu buruk bagi nasabah.

\section{Motivasi Menabung}

Istilah motivasi berasal dari bahasa latin, yakni movere, yang berarti menggerakkan. Motivasi bisa dikatakan sebagai energi untuk membangkitkan dorongan dalam diri dan diakhiri dengan penyesuaian diri. Penyesuaian diri dikatakan untuk memuaskan motif. ${ }^{24}$

Motivasi menabung dimiliki oleh setiap manusia, tetapi ada sebagian orang yang lebih giat menabung dari pada yang lain. Kebanyakan orang mau bekerja lebih keras jika tidak menemui berbagai jenis hambatan agar dapat merealisasikan yang sudah diharapkan. Selama dorongan kerja itu kuat, semakin besar peluang individu untuk lebih konsisten pada tujuan kerja. Ada juga yang menyukai dorongan kerja tanpa mengharapkan imbalan, sebab ia menemukan kesenangan dan kebahagiaan dalam perolehan kondisi yang dihadapkan dan dalam mengatasi situasi yang sulit.

Motivasi adalah dasar yang utama yang mempengaruhi untuk memberikan suatu dorongan dan gerakan, memberikan dinamisator dan mekanismenya dalam bekerja serta memberikan suatu keputusan yang bersifat rohani, karena telah diketahui bahwa motivasi adalah suatu aspek psikologi yang merupakan dorongan atau alasan dari seorang untuk melakukan suatu kegiatan, sehingga dengan motivasi yang kuat maka

\footnotetext{
${ }^{22}$ Rambat Lupiyoadi, Manajemen Pemasaran, (Jakarta: Salemba Empat, 2001), h. 140.

${ }^{23}$ Fandy Tjipto, Strategi Pemasaran Jilid II, (Yogyakarta: Andi Offset, 2001), h. 140.

${ }^{24}$ Anwar Mangkunegara, Manajemen Sumber Daya manusia perusahaan, (Bandung: PT. Rosda Karya, 2004), h. 93.
} 


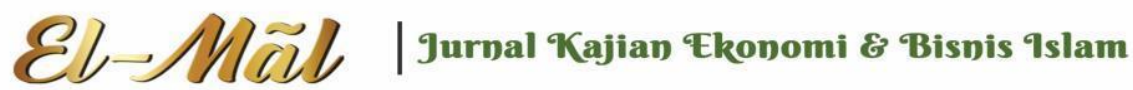

\section{Vol 2 No 2 (2019) 234-251 P-ISSN 2620-295 E-ISSN 2747-0490 DOI: $1047467 /$ elmal.v2i2.550}

akan melahirkan minat dengan minat tersebut maka akan menjadikan siswa itu lebih giat dalam melakukan aktivitas yang bermanfaat dan memajukan perusahaan.

Seperti kita ketahui bahwa motivasi itu terdapat dalam individu, namun dapat terlihat dari luar melalui gejal tingkah laku yang muncul pada individu tersebut, karena motivasi adalah suatu penentu tingkah laku atau "Action" yang timbul pada suatu objek tertentu. Sama halnya dengan minat yang tidak dapat dilihat dari luar karena minat merupakan suatu pengamatan perasaan, namum minat yang timbul dari kebutuhan anak akan menjadi factor pendorong dari dalam untuk melakukan pekerjaan yang dilakukan karena menarik minatnya untuk melakukannya.

Setiap manusia memiliki kecenderungan yang fundamental untuk berhubungan dengan sesuatu yang berada dalam lingkungannya, jika hal tersebut memberikan kesenangan pada dirinya kemungkinan dia akan berminat terhadap sesuatu tersebut.

Minat muncul apabila seseorang tertarik kepada sesuatu karena sesuai dengan kebutuhannya atau merasakan bahwa sesuatu itu berguna bagi dirinya. Kebutuhan disini yaitu seperti kebutuhan akan aktualisasi diri, kebutuhan estetis, kebutuhan kognitif, kebutuhan akan penghargaan, kebutuhan cinta dan rasa memiliki, kebutuhan akan keamanan dan kebutuhan fisiologi.25

Dilihat dari segi bahasa minat berarti "kecenderungan hati yang tinggi terhadap sesuatu, gairah, keinginan". ${ }^{26}$ Menurut WJS. Poerwadarminta dalam kamus umum Bahasa Indonesia menyatakan bahwa minat adalah perkataan atau ungkapan, kesukaan (kecenderungan hati) kepada sesuatu. ${ }^{27}$ Slameto berpendapat minat adalah " suatu rasa lebih suka dan rasa ketertarikan pada suatu hal atau aktivitas tanpa ada yang menyuruh".28

Dari beberapa pendapat ahli psikologis diatas, dapat disimpulkan minat adalah suatu kecenderungan yang erat kaitannya dengan perasaan terutama perasaan senang terhadap sesuatu yang dianggap berharga atau sesuai kebutuhan dan memberikan kepuasan kepadanya. Sesuatu itu dapat berupa aktivitas orang. Minat dan motivasi adalah satu komponen yang sama. Minat muncul karenan ada nya motivasi yang kuat.

Setelah kita mengetahui begaimana kita memahami kehadiran motivasi bagi karyawan yang berfungsi sebagai pendorong dan motivator dari dalam untuk dapat memberikan kondisi yang produktif untuk mencapai tujuan dalam bekerja, maka perlu kita ketahui faktor-faktor yang mempengaruhi motivasi tersebut sehingga kita dapat

${ }^{25}$ Nigel C. Benson dan simon Grove, Mengenal Psikologi For Begining, (Bandug: Mizan:2000), cet ke-1, h. 110.

${ }^{26}$ Tim Penyusun Kamus, Kamus Besar Bahasa Indonesia, (Jakarta:Balai Pustaka,1990), cet ke-3, h. 568.

${ }^{27}$ WJS. Poerdarminta, Kamus Umum Bahasa Indonesia, (Jakarta:PN Balai Pustaka,1992), h. 650 .

28 Slameto, Balajar dan Faktor-faktor yangMempengaruhinya,(Jakarta:PT. Adi Mahasatys,2002), cet ke-4, h. 180. 


\section{Vol 2 No 2 (2019) 234-251 P-ISSN 2620-295 E-ISSN 2747-0490 DOI: $1047467 /$ elmal.v2i2.550}

memperhitungkan hal yang terjadi. Untuk dapat mengetahui faktor-faktor yang mempengaruhi motivasi, maka lebih dahulu harus dikenal jenis-jenis motivasinya. Secara umum ada dua jenis motivasi ditinjau dari factor yang mempengaruhinya, yaitu motivasi instrinsik dan motivasi ekstrinsik. ${ }^{29}$ Secara lebih jelas akan diuraikan sebagai berikut : Motivasi Instrinsik dan Motivasi ekstrinsik/eksternal.

\section{Faktor yang mempengaruhi nasabah menabung di Bank Muamlat}

\section{Bagi hasil}

Bagi hasil menurut terminologi asing (Inggris) dikenal dengan profit sharing. Profit shar ing dalam kamus ekonomi yaitu pembagian laba. Secara definitif profit sharing artinya distribusi beberapa bagian dari laba pada para pegawai dari suatu perusahaan. ${ }^{30}$ Pada mekanisme lembaga keuangan syari'ah atau bagi hasil, pendapatan bagi hasil ini berlaku untuk produk-produk penyetoran, baik penyetoran menyeluruh maupun sebagian-sebagian, atau bentuk bisnis kooperatif (kerjasama). Keuntungan yang dibagi hasilkan harus dibagi secara proporsional antara shahibul mal dengan mudharib. Dengan demikian, semua pengeluaran rutin yang berkaitan dengan bisnis mudharabah, bukan untuk kepentingan pribadi mudharib, dapat dimasukkan ke dalam biaya operasional.

\section{Pelayanan}

Pelayanan adalah kunci keberhasilan dalam berbagai usaha atau kegiatan yang bersifat jasa. Peranannya akan lebih besar dan bersifat menentukan manakala dalam kegaiatan-kegiatan jasa di masyarakat itu terdapat kompetisi dalam usaha merebut pasaran atau langganan. Suatu perusahaan seperti perbankan untuk menarik perhatian nasabah harus memiliki layanan yang baik agar nasabah merasa puas.

Pelayanan atau jasa (service) adalah suatu hasil (product) dari kegiatan hubungan timbal balik antara producer dan costumer dengan melalui beberapa kegiatan internal, producer dapat memenuhi kebutuhan costumer dalam bentuk kepuasan (satisfaction). ${ }^{31}$

\section{Pendapatan}

Pendapatan merupakan jumlah yang dibebankan kepada langganan atas barang dan jasa yang dijual, dan merupakan unsur yang paling penting dalam sebuah perusahaan, karena pendapatan akan dapat menentukan maju-mundurnya suatu

${ }^{29}$ Saiful Bahri Djamarah, Psikologi Belajar, (Jakarta: PT Rieneka Cipta,2011), h. 149.

30 Wirdyaningsih,dkk, Bank dan Asuransi Islam di Indonesia, (Jakarta : Kencana Prenada Media, 2005),h.61

${ }^{31}$ H.A.S Moenir, Manajemen Pelayanan Umum di Indonesia, (Jakarta : Bumi Aksara, 2006), h. 17 


\section{Vol 2 No 2 (2019) 234-251 P-ISSN 2620-295 E-ISSN 2747-0490 DOI: $1047467 /$ elmal.v2i2.550}

perusahaan. Oleh karena itu perusahaan harus berusaha semaksimal mungkin untuk memperoleh pendapatan yang diharapkannya. Pendapatan pada dasarnya diperoleh dari hasil penjualan produk atau jasa yang diberikan.

\section{Religiulitas}

Religiulitas adalah salah satu komponen bahasan dalam ilmu psikologi, khususnya psikologi agama. Memang sangat sulit mengembangkan salah satu disiplin ilmu ini, karena ada beberapa rintangan dan kekurangan serta keterbatasan dalam mempelajari sikap religius seseorang, diantaranya agama itu sendiri susah diempiriskan, melanggar norma agama dan kepercayaan adalah hal yang bersifat abstrak.

Dalam diskursus keagamaan kontemporer, dijelaskan bahwa agama ternyata bukan lagi seperti orang dahulu memahaminya, yakni hanya semata-mata terkait dengan persoalan ketuhanan atau keimanan saja. Keberagamaan (religiuistas) diwujudkan dalam berbagai sisi kehidupan manusia. Aktifitas beragama tidak hanya terjadi ketika seseorang melakukan perilaku ritual (ibadah), tetapi apresiasi terhadap ajaran agama. Tersebut juga telah diaplikasikan dalam kegiatan duniawi atau kemasyarakatan termasuk perbankan.

Dengan demikian, keagamaan atau religi adalah keyakinan manusia yang tinggi terhadap ajaran agamanya, sehingga menimbulkan kesadaran dalam dirinya untuk tunduk dan patuh sepenuhnya dalam melaksanakan ajaran agamanya.

Dalam kaitan itu, umat Islam yang tingkat emosionalnya tinggi akan tunduk dan patuh terhadap fatwa Majelis Ulama Indonesia (MUI) bahwa sistem bunga yang diterapkan di perbankan konvensional adalah riba dan hukumnya haram, karena terjadi kesamaan illat (sebab) pada nilai hukum bunga dan riba. Keharaman riba jelas tidak diragukan lagi, karena hal itu sudah ditegaskan Allah SWT dalam Al-Qur'an. Ayat tentang keharaman riba bisa dilihat dalam empat Surat dalam Al-Qur'an. Pertama, dalam Surat Ar-Ruum ayat 39 yang berbunyi :

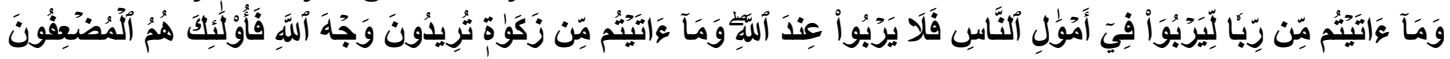

Artinya: "Dan sesuatu riba (tambahan) yang kamu berikan agar dia bertambah pada harta manusia, maka riba itu tidak menambah pada sisi Allah. Dan apa yang kamu berikan berupa zakat yang kamu maksudkan untuk mencapai keridhaan Allah, maka (yang berbuat demikian) itulah orang-orang yang melipat gandakan (pahalanya)". ${ }^{32}$

\section{Penelitian Sebelumnya}

Adapun penelitian sebelumnya yang terkait dengan Analisis Pengetahuan Nasabah Mengenai Pelayanan Perbankan Syariah Sebagai Motivasi Menabung Di Bank Muamalat Cabang Pembantu Stabat adalah penelitian oleh Nailus Sa'adah tahun 2010 yang berjudul Analisis terhadap alasan masyarakat untuk menjadi nasabah BNI Syariah

\footnotetext{
${ }^{32}$ Departemen Agama Republik Indonesia, Al-Qur'an dan Terjemahan,.... h. 462.
} 


\section{Vol 2 No 2 (2019) 234-251 P-ISSN 2620-295 E-ISSN 2747-0490 DOI: $1047467 /$ elmal.v2i2.550}

ditinjau dari persfektif marketing mix yang menyimpulkan bahwa marketing mix yang menjadi alasan nasabah untuk menabung di BNI Syariah.

\section{METODE PENELITIAN}

Penelitian ini menggunakan penelitian deskriptif. Penelitian deskripif dimaksudkan untuk memperoleh gambaran dengan cara menganalisis dan menafsirkan variabel-variabel yang diteliti. Sehingga nampaklah bahwa penelitian ini merupakan penelitian kualitatif dan bersifat deskriptif analitis.

Metode yang digunakan untuk mengumpulkan data dalam penelitian ini adalah wawancara, observasi dan dokumentasi. Wawancara lebih fokus kepada sumber data primer yang ada yaitu orang yang berkaitan langsung dengan variabel penelitian. Untuk observasi dilakukan dengan pengamatan langsung obyek maupun lokasi penelitian tersebut. Sedangkan dokumentasi yang terkumpul adalah proses penelitian yang dilakukan dari awal hingga akhir penelitian.

Tempat peneliti mengenai Pelayanan Yang Baik Terhadap Nasabah Sebagai Motivasi Menabung Di Bank Muamalat Cabang Pembantu Stabat adalah di Bank Muamalat Cabang Pembantu Stabat.

Sumber data, sebagai berikut: Data primer adalah data yang diperoleh dari instansi atau lembaga terkait yang dianggap relevan dengan tujuan penelitian melalui dokumentasi, observasi, wawancara dan kuisioner dan Data sekunder adalah data yang diperoleh melalui penulusuran berbagai referensi yang terkait dengan Pelayanan Yang Baik Terhadap Nasabah Sebagai Motivasi Menabung Di Bank Muamalat Cabang Pembantu Stabat. Adapun data sekunder tersebut terdiri atas: buku-buku, undangundang, artikel, majalah, ensiklopidia, kamus, dan bahan acuan lainnya.

Metode pengumpulan data yang digunakan dalam penelitian ini Observasi adalah metode pengumpulan data yang digunakan untuk menghimpun data penelitian melalui pengamatan dan penginderaan. ${ }^{33}$ Observasi dalam penelitian ini adalah melakukan pengamatan langsung di lapangan untuk mengetahui kondisi subjektif di seputar lokasi penelitian yaitu Pelayanan Yang Baik Terhadap Nasabah Sebagai Motivasi Menabung Di Bank Muamalat Cabang Pembantu Stabat. Dokumentasi berasal dari kata dokumen yang artinya barang-barang yang tertulis. Dalam melaksanakan metode dokumentasi, peneliti menyelidiki benda-benda tertulis seperti buku-buku, majalah, dokumen, catatan harian, dan sebagainya. Hasil penelitian dari observasi dan wawancara, akan lebih kridibel/dapat dipercaya bila didukung dengan dokumentasi. Wawancara merupakan tekhnik pengumpulan data untuk mendapatkan keterangan lisan melalui tanya jawab dan berhadapan langsung dengan orang yang memberikan keterangan terkait objek

${ }^{33}$ Burhan Bungin, Penelitian Kualitatif, (Jakarta: Kencana, 2009), h. 15 


\section{Vol 2 No 2 (2019) 234-251 P-ISSN 2620-295 E-ISSN 2747-0490 DOI: $1047467 /$ elmal.v2i2.550}

masalah yang di angkat oleh peneliti. ${ }^{34}$ Dalam penelitian ini menggunakan wawancara terstruktur dan semiterstruktur, yakni dialog oleh peneliti dengan informan yang dianggap mengetahui jelas Pelayanan Yang Baik Terhadap Nasabah Sebagai Motivasi Menabung Di Bank Muamalat Cabang Pembantu Stabat.

Penelitian ini menggunakan unit analisis Nonprobability Sampling. Nonprobability sampling adalah teknik pengambilan sampel yang tidak memberi peluang atau kesempatan yang sama bagi setiap unsur (anggota) populasi untuk dipilih menjadi sampel. Subyek yang diteliti adalah pimpinan nasabah dan Karyawan Bank Muamalat Cabang Pembantu Stabat. Sedangkan yang dijadikan informan dalam penelitian adalah semua orang maupun lembaga yang terkait dengan penelitian.

\section{HASIL DAN PEMBAHASAN}

Berdasarkan hasil wawancara yang peneliti lakukan terhadap kepala cabang, karyawan, dan nasabah. Hasil wawancara dengan kepala cabang Bank Muamalat Cabang pembantu Stabat, keadaan lingkungan bank Muamalat Cabang Pembantu Stabat sangat strategis, karena berada di jalan lintas kota Stabat. Terdapat sarana dan prasarana yang sangat lengkap, dan membantu nasabah untuk bertransakasi. Bank Muamalat adalah Bank Syariah pertama di Indonesia. Struktur organisasi Bank Muamalat sangat baik sama seperti Bank Syariah pada umumnya. Sarana dan prasara yang dimiliki sangat lah lengkap, mulai dari gedung, karyawan dan fasilitas yang lainnya. Lokasi nya yang sangat strategis, sehingga memudahkan masyarakat untuk menabung. Kepala cabang adalah pimpinan yang tertinggi di dalam dunia perbankan.

Pemimpin adalah orang yang mampu mempengaruhi anggota nya untuk menjalankan roda organisasi dengan baik. Pemimpin harus bisa memotivasi karyawannya agar memiliki semangat yang baik ketika bekerja. Dan karyawan juga harus bisa memotivasi nasabah, agar mereka memiliki loyalitas yang tinggi untuk menabung di Bank Muamalat Cabang Pembantu Stabat.

Wawancara dengan nasabah Bank Muamalat Cabang pembantu Stabat mengenai Pelayanan yang baik terhadap nasabah sebagai motivasi menabung di Bank Muamalat Cabang Pembantu Stabat Menurut Kurniawan, salah satu nasabah Bank Muamalat, yang berprofesi sebagai karyawan swasta, " segala urusan dipermudah ketika ingin bergabung menjadi nasabah, karyawan Bank Muamalat Stabat sangat bagus, sopan dan ramah. Intinya banyak keuntungan yang didapat ketika bergabung mejadi nasabah, pelayanan yang sangat baik diberikan kepada semua nasabah sehingga banyak nasabah termotivasi menabung di Bank Muamalat". Menurut Mawaddah, pekerjaan sebagai guru, berpendapat " saldo awal untuk menabung sangat murah atau sedikit, tidak memakai

${ }^{34}$ Husain Usman dan Purnomo Setiady Akbar, Metodologi Penelitian Sosial, (Cet. IV; Jakarta: PT. Bumi Aksara, 2001), h. 73. 


\section{Vol 2 No 2 (2019) 234-251 P-ISSN 2620-295 E-ISSN 2747-0490 DOI: $1047467 /$ elmal.v2i2.550}

sistem bunga, melainkan sistem bagi hasil, proses menabung sangat mudah dan Karyawan sangat santun, ramah dan sopan, serta memberikan penjelasan yang sangat mudah dimengerti oleh nasabah, serta komunikasi antar nasabah dan karyawan yang sangat baik.

Menurut Maimunah, seorang ibu rumah tangga, hampir sama jawabannya dengan nasabah lainnya, karyawan Bank Muamalat sangat baik, ramah dan sopan. Serta memberikan pelayanan yang sangat baik, tidak pernah membedakan profesi antar para nasabah. Ahmad Lailan, seorang petani, " segala urusan dipermudah, menggunakan sistem bagi hasil. Karyawan sangat sopan, memberikan penjelasan dan pelayanan yang sangat baik. Memberikan motivasi yang sangat baik kepada nasabah, sehingga banyak nasabah yang sangat senang menabung di Bank Muamalat Stabat.

Jadi dapat disimpulkan, etika berbicara, sikap yang diberikan karyawan kepada para nasabahnya sangat baik dan banyak nasabah yang memuji sehingga termotivasi untuk menabung di Bank Muamalat cabang Pembantu Stabat.

Hasil wawancara dengan Karyawan Bank Muamalat cabang Pembantu Stabat, menjadi karyawan Bank adalah pekerjaan yang cukup menantang dan membutuhkan kesabaran. Menghadapi nasabah, memberikan senyum, berbicara dengan sopan dan santun serta ramah tamah. Sering kali menghadapi nasabah yang kurang paham mengenai produk dan menangani tata cara menabung, itu tugas dari karyawan untuk menjelaskan. Memberikan penjelasan yang mudah dimengerti oleh nasabah dan selalu mengedepankan profesionalitas dalam bekerja. Karyawan adalah orang yang paling depan menghadapi keluhan dari nasabah, untuk itu dituntut agar dapat memberikan kenyamanan kepada nasabah ketika dia sedang menjelaskan permasalahan yang dihadapi nasabah dan segera bisa mencari solusi.

Kesimpulannya, sebagai karyawan harus bertanggung jawab. Sopan dan ramah. Menjunjung profesionalisme dan tepat waktu serta mandiri. Antara pimpinan, karyawan dan nasabah haruslah memiliki komunikasi yang baik, agar roda organisasi yang baik akan terjalin. Saling memberi motivasi agar karyawan loyal dalam bekerja dan nasabah loyal dalam menabung.

Dari pemaparan diatas, dapat disimpulkan bahwasannya pelayanan yang baik terhadap nasabah berpengaruh positif dan signifikan terhadap nasabah Bank Muamalat Cabang Pembantu Stabat.

\section{KESIMPULAN DAN SARAN}

Berdasarkan hasil penelitian dan pembahasan dengan ini menyimpulkan bahwa pelayanan yang diberikan oleh Bank Mamalat Cabang Pembantu Stabat sangat baik, mereka melayani nasabah denga sepenuh hati. Sikap yang ditunjukan sangat sopan dan ramah. Nasabah merasa sangat nyaman berada di Bank Muamalat. 


\section{Vol 2 No 2 (2019) 234-251 P-ISSN 2620-295 E-ISSN 2747-0490 DOI: $1047467 /$ elmal.v2i2.550}

Karyawan yang ramah serta sopan adalah salah satu cara untuk meningkatkan motivasi menabung kepada nasabah. Karyawan tidak pernah membedakan antara nasabah yang satu dengan nasabah yang lain.

Faktor yang meningkatkan motivasi nasabah menabung adalah faktor pelayanan yang baik yang diberikan oleh Bank Muamalat, sehingga membuat nasabah menjadi loyal untuk menabung di Bank tersebut. Selain itu juga kondisi Bank serta lokasi Bank juga salah satu faktor pendukung. Lokasi yang mudah dijangkau oleh transportasi apapun dan terletak di kota stabat, memudahkan nasabah untuk menabung.

Adapun saran yang diharapkan adalah Bank Muamalat Cabang Pembantu Stabat hendaknya lebih meningkatkan lagi hubungan kerja dan komunikasi yang efektif antar pimpinan, karyawan dan nasabah dan Bagi karyawan saya harap dapat meningkatkan motivasi dalam bekerja agar nasabah yang menabung menjadi lebih nyaman dan bisa menarik para calon nasabah untuk bergabung menjadi nasabah Bank Muamalat Cabang Pembantu Stabat.

\section{DAFTAR PUSTAKA}

Al-Qur'anul Karim Al-Qur'an dan Terjemahannya

Ali, M.B., dan Isman, William H, Kamus Lengkap Bahasa Indonesia, 2001, Bandung , Citra Umbara.

Antonio, M. Syafi'i, Bank Syariah Dari Teori ke Praktek, 2001, Jakarta:Gema Insani.

Arikunto, Suharsimi, Prosedur Penelitian Suatu Pendekatan Praktek, 1998, Jakarta : PT. Rineka Cipta.

Benson, Nigel C. dan simon Grove, Mengenal Psikologi For Begining, 2000, Bandug: Mizan. Departemen Agama RI,Al-Qur'an dan Terjemah, 2010, Jakarta: Pustaka assalam. Hazim, Nur Khalif dan A.R.Elhan, kamus Ilmiah Populer, 2003, Surabaya:karya Ilmu.

Karim, Adiwarman A., Bank Islam: Analisis Fiqih dan Keuangan, 2004, Jakarta:PT.Raja Grafindo Persada.

Kashmir,Manajemen Perbankan,Edisi Revisi ke-10, 2011, Jakarta:Rajawali Pers.

Muhammad, Manajemen Bank Syariah, Edisi Revisi ke-2, 2011, Yogyakarta:UPP STIM YKPN.

Muhammad, Dasar-dasar Manajemen Bank Syariah Edisi Revisi, 2006, Yogyakarta:UII Pres.

Poerdarminta, WJS., Kamus Umum Bahasa Indonesia, 1992, Jakarta:PN Balai Pustaka.

Ridwan, Belajar Mudah Penelitian, 2004, Bandung:Alfabeta.

Singarimbun, Masri dan Sofyan Effendi, eds, Metode Penelitian Survai, 1990, Jakarta : LP3ES, Cet. VIII. 


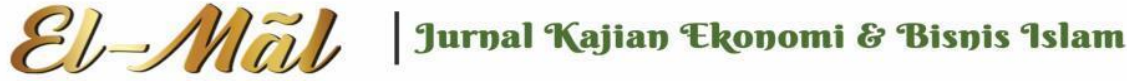

\section{Vol 2 No 2 (2019) 234-251 P-ISSN 2620-295 E-ISSN 2747-0490 DOI: $1047467 /$ elmal.v2i2.550}

Slameto, Balajar dan Faktor-faktor yang mempengaruhinya, 2002, Jakarta:PT. Adi Mahasaty.

Sudijono, Anas, Pengantar Statistik Pendidikan, 2008, Jakarta:CV. Raja Grafindo persada.

Soetrisno, Eddy, Kamus Populer Bahasa Indonesia, 2010, Bandung:Sinergi Pustaka Indonesia.

Tim Pustaka Agung Harapan, Kamus Ilmiah Populer, 2012, Surabaya:pustaka Agung Harapan.

Tim Penyusun Kamus, Kamus Besar Bahasa Indonesia, 1990, Jakarta:Balai Pustaka, cet ke3. 